\title{
Ubuntu in the worship service as heterotopia: A liturgical-ecclesiological exploration
}

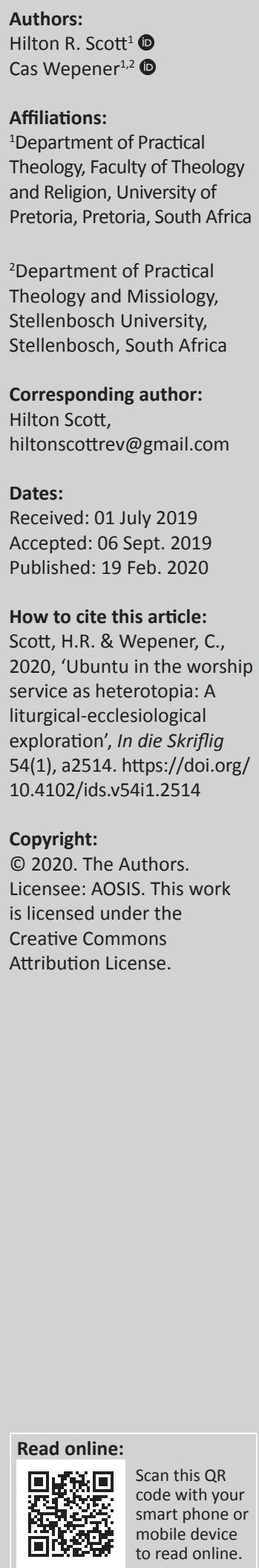

Through taking an interdisciplinary approach to studying liturgy, a connection has been made in this article between three theological concepts: koinonia, liturgical inculturation and the utopian ideal of inclusivity in the form of 'heterotopias'. These concepts are all, to some degree, comparable to the African concept of $u b u n t u$, an ideal or utopia in itself. This article aims to draw comparisons between the collection of normative ideals above and a current multicultural church context empirically researched in postcolonial and pluralistic church societies - in postapartheid South Africa. These comparisons are made as a process of critical interference by doing an empirical probe by asking 'what is happening', and a normative probe, which asks 'what should be happening'. This involves investigating the actual liturgical praxis of worshipping communities in order to navigate toward and better understanding of an inclusive society as depicted by the concepts of the Rainbow Nation or Ubuntu. The conclusion shows that which 'ought to be happening' in worship that serves our current South African realities is - to an extent - already happening in some worshipping communities. Insights gained from the liturgical praxis of these communities can serve as best practices for other communities.

Keywords: Liturgical Inculturation; Liturgical Interculturation; Inclusivity; Exclusivity; Prayer; Liturgical Rituals; Ubuntu; Practical Theology; Heterotopia.

\section{Introduction}

Essentially, all Christians are members of the body of Christ - or should be - according to the Pauline concept. Understanding ubuntu as 'I am because we are' is similarly to the concept of Christians being part of the body of Christ. This is to see that the ' $I$ ' forms an inseparable part of the 'we' as a worshipping community - or network - through common participation (cf. Scott 2018:193; Thiselton 2015:313-314). Such is the flow of the network society that even those in the periphery are considered members of the same body as those participants in the worship service (cf: Barnard 2010). This is to say that there are, in more ways than one, perforated boundaries that allow Christians to be a part of the body of Christ. In terms of liminal spaces 'an alternate form of human interrelatedness can come into existence', namely communitas ${ }^{1}$ (cf. Barnard 2010:70; Turner 1995:96). Thus, a statement such as: 'If a person was not part of a community of God's people "in Christ", that individual would hardly be "Christian"!' (Thiselton 2015:311), can be adapted so that the notion of 'communitas' replaces 'community'. This is underlined by Volf (1996:40), who explains that ' $[a] \mathrm{t}$ the very core of Christian identity lies an all-encompassing change of loyalty, from a given culture with its gods to the God of all cultures'.

In this sense, it will be argued here that the liturgical (and ritual) experiences of Christians can become a 'way of life', as is indicated by an understanding of the 'septuple rhythm' ${ }^{2}$ described by Wolterstoff (cf. 2011:19-21). Therefore, how 'we' worship, in terms of the aphorism 'lexorandi, lexcredendi, lex(con)vivendi', ${ }^{3}$ should affect how ' we' live (together). By approaching the complexities of living in a postcolonial (or postapartheid) multicultural, multiracial and multifaith environment through the lenses of Ritual Studies, this context can be regarded as one with a preliminal, liminal and postliminal phase (cf. Wepener 2006a; 2009; 2015).

Thus, the perception is that through worship(ping), inclusively as a result of an (expected) allencompassing change of 'loyalty' to the God of all cultures, 'we' should believe inclusively and therefore live inclusively devoid of discrimination, hatred, racism and fear of the Other or difference. In certain instances, that which should be happening is already happening, although in 1.Communitas is also a space with potential (cf. Wepener $2014 \mathrm{~b}: 29$ ).

2.This notion denotes that which is experienced in the liturgy extends into the week following the service, or the liturgy is the conclusive response of that which happened in the week preceding the service (cf. Scott 2018:162; Wolterstoff 2011:24).

3.See Smit (2004): 'Lex orandi, lex credendi, lex (con)vivendi? - Oriënterende inleiding tot liturgie en etiek'. 
the form of 'heterotopias'. A 'heterotopia' is 'a space wherein utopia becomes visible and tangible, real and traceable' (Van Wyk 2014:4). ${ }^{4}$ The role of a heterotopia can be to 'create a space that is other, another real space, as perfect, as meticulous, as well arranged as ours is messy, ill constructed and jumbled' (Foucault \& Miskowiec 1986:27).

In John 15, the allegory of the vine and the branches depicts a scenario where all that remain in Jesus as the vine, will, as branches, bear fruit. Fittingly, this chapter proceeds to explain what is of paramount importance in this article and the current South African context: 'My command is this: Love each other as I have loved you' - a heterotopia in itself. In a larger South African context especially, this has been complicated by discrimination and more obviously by the forced segregation of different (or the Other) people during the years of apartheid which has strongly discouraged accepting otherness (cf. Ackermann 1998) and is marred furthermore in the present by extremist 'political' groups or the 'fears' of 'the other' (Van Wyk 2014:1). In terms of the above commandment, this love is transcultural according to the Nairobi Statement on Worship and Culture, in other words, it is: ' . . the same substance, for everyone everywhere, beyond culture' (Lutheran World Federation 1996:1). This poses an initial research question: How could current liturgical praxis as heterotopia aid the development and imagining of ubuntu in South Africa?

The question above will be responded to by using empirical data from a research project that was conducted during 2015 and 2016, where qualitative participatory observations and semi-structured interviews were conducted (cf. Scott 2018) ${ }^{5}$ as well as a review of current literature. The aim of this approach is to develop a descriptive-empirical setting that details 'what is going on', which aids in discerning patterns and dynamics in certain episodes, situations and contexts (cf. Osmer 2008:4, 31-78). For the purposes of this article, an interdisciplinary approach has been taken. The concept, in short, is understood to be an alliance between fields of study, which leads to an integration of separate theories from different disciplines. For this article, the integration of the theories from Liturgical Studies, Ritual Studies and Systematic Theological Ecclesiology cultivates new knowledge by '(re) defining the relationships of the disciplines, developing integrative concepts and generating unconventional insights' (Scott 2018:21-23; also cf. Lunsford, Wilson \& Eberly 2009:278). As mentioned above, the context of 'what is going on' can then be responded to by considering the relative theory from the arts and sciences as well as using theological concepts. Thus, understanding 'what is going on' through interpreting the situations and contexts, then learning from 'good practice', developing ethical norms and 'criticising utopia' (cf. Osmer 2008:4; Scott 2018:16, 40, 131, 168; Van Wyk 2014:4; Wepener 2009:32).

\footnotetext{
4. See Van Wyk (2014:4) for a description of 'utopian thinking', where among other descriptions 'utopia' is seen as '"space" for the future', thus a normative ideal.

5.The semi-structured interview questions relevant to this article are shared where applicable.
}

\section{First impressions}

There is a clear distinction within the field of Liturgical Studies, that there are various reciprocations between culture and the liturgical tradition(s) of the church (cf. Barnard 2010; Barnard, Cilliers \& Wepener 2014; Chupungco 1992; Lutheran World Federation 1996; 1998 as examples). A common praxis model within the field is liturgical inculturation, which is the 'continuous process of critical-reciprocal interaction between cult (liturgy) and culture so that a totally new entity comes into being, namely an inculturated liturgy' (cf. Wepener 2009:42). Thus, one of the aims of liturgical inculturation (and liturgical interculturation) is inclusivity in terms of cultural relevance (Scott 2018:179). Similarly, the nation's constant reference to the utopia of $u b u n t u$ aims at cultivating inclusivity. However, with the current concerns over unity and inclusion in South Africa, it may appear that re-establishing 'The Rainbow Nation' ${ }^{6}$ - from a 'church' perspective - considers more than the reciprocal interactions between cult and culture. Thus, the aphorism 'lexorandi, lexcredendi, lex(con)vivendi' (Smit 2004 ) is helpful in navigating towards an inclusive society.

Loosely translated this aphorism illustrates that 'as we pray (or worship), so we believe, so we live (together)' (cf. Scott 2018:1;Smit 2004). In the case that our liturgies are inculturated, so also should our beliefs be; furthermore, we should be living in an inculturated - or interculturated - manner (cf. Wepener 2006). In a normative sense, a new entity would come into existence such as the Rainbow Nation, or a society fixated on applying the concept of Ubuntu. Buqa (2015:4) writes that: 'Xenophobia, racism, gang activities, corruption, inequality, nepotism and poverty are not part of Ubuntu and are not presenting the ideal of the Rainbow Nation of Madiba'. Five years prior to this, Cilliers (2010) wrote:

South Africans at present exist within an in-between space, where we have achieved political freedom, but at the same time are still struggling with issues such as poverty, HIV and AIDS, unemployment, crime, corruption, and the collapse of certain value systems. (p. 344)

A quarter of a century since the dawn of democracy, this situation persists as South Africans remain in this 'in-between space', or as scholars of Ritual Studies write: 'betwixt and between' (cf. Turner 1995:107; Van Gennep 1960). Added to these struggles, although it is not new, is the ongoing dynamics of dealing with otherness (or difference) where new terminology is being dubbed - for example 'white fragility' (DiAngelo 2018). There is firstly the opportunity for forward steps to be taken in the phase of transition, as referred to by Cilliers (2010:344), and secondly to reestablish, reiterate and perhaps even reinvent the concepts of a Rainbow Nation and Ubuntu by recognising where South Africa is today. While focusing on what ought to be happening, a quote from Eldridge Cleaver is helpful in qualifying the church's role in recognising Ubuntu: 'There is no more neutrality in the world. You either have to be a part of the solution, or you're part of the problem'.

6.As described by Desmond Tutu and further used by Nelson Mandela (Buqa 2015:1) 


\section{What has been going on?}

As mentioned in the introduction, qualitative empirical research was conducted during 2015 and 2016 in the form of participatory observations and semi-structured interviews. The participatory observations were recorded in two ways: firstly and foremost, in the form of 'thick descriptions' (cf. Geertz 1973:3-30; Ponterotto 2003:538-549); and secondly with a dictaphone that served as an 'extra to personal observations by a critical scholarly observer and wellobserved and documented written field notes' (Wepener \& Barnard 2010:206). The decision to conduct semi-structured interviews ${ }^{7}$ lies in Osmer's (2008:63) explanation of the process involving: 'asking both open-ended and closedended questions in a planned sequence, which is adapted to the emerging flow of the conversation'. Importantly, the word conversation should be emphasised, as it allowed for more expressive, emotive responses contrary to stoic-like responses prompted by structured interviews (cf. Scott 2013:11; 2018:49).

Osmer (2008:12) describes 'episodes, situations or contexts' that are understood or interpreted by drawing on theories from the arts and sciences (Osmer 2008:83). It is necessary to describe the general context that was observed and documented by means of the qualitative research mentioned above. This is done in order to describe what is going on, which then allows further questions to be asked such as 'What ought to be going on?' (Osmer 2008:4). It is understood, for the purposes of this study, that:

A context is composed of the social and natural systems in which a situation unfolds. A system is a network of interacting and interconnected parts that give rise to properties belonging to the whole, not to the parts.... Context, thus, serves a flexible purpose, calling attention to micro- and macrosystems that are relevant to a given case. Moreover, systems are open and dynamic. They are influenced by other systems. (p. 12)

According to the above, certain social systems of which this context has been composed, have already been illuminated by describing the 'first impressions' above. Following, this context will be described further by doing an empirical probe as part of employing interference (see Post 2001:58-59). This will be done by categorising the appropriate findings into themes.

\section{Neither here nor there}

It is apparent that the majority that were interviewed for the initial research project, take an impartial approach to opportunities for inclusive - or group - prayer (lexorandi 'as we pray'). The rest of the interviewees preferred to pray alone, explaining that their preference was primarily due to them being shy, 'not being extroverted', or that their prayers were personal. In other words, given the option to pray alone or in a group, ${ }^{8}$ more than half of the interviewees were impartial, as can be seen by the examples quoted below:

7.Compare Babbie and Mouton (2001:289-291); Gubrium, Holstein and Marvasti (2012:193-205); Scott (2013:11; 2018:48-50); Thumma (1998:203-208) and Wepener (2014a:2).

8.The interview question asked: 'Do you prefer praying alone, in a group or both?' (Scott 2018:50)
- 'Either-or, depending on the circumstances'.

- 'Either-or, I'm not fussed. I will pray aloud, I will pray with a group, I pray on my own and so I'm not phased because I have to speak aloud'.

- 'Either, it doesn't bother me if I pray alone or in a church'.

- 'I'm easy, I do pray alone but I also pray in a group'.

From the participatory observations, ${ }^{9}$ it was documented that an African choir led the congregation in worship for one of the liturgical services. This appeared to not be as well received as intended, as many of the worshippers in the congregation found it difficult to follow the choir and their renditions of the hymns. Besides this rather isolated incident in general all participants, across the churches where the research was conducted, seemed to be engaged with the liturgical traditions. This is not to say that the worshippers were not accepting the liturgy that was being led by the African choir, rather that this attempt at cultural bricolage had not completely filled its intended purpose (cf. Barnard et al. 2014:117-130). It can be speculated that the intention was to expose the liturgical tradition and norms to a culture (and language) that is less prominent in that specific congregation. Hence, 'bricolage' is used in this context to describe a traditional African choir leading worship in a church that consists mostly of worshippers who are accustom to the long-standing traditions of the church.

The term utopia has already been used and briefly described in the introduction. The premise of 'utopia' as a concept, of an ideal. Van Wyk (2014) discusses the differences between 'utopia(s)' and 'heterotopia(s)' - both are ideals. The difference is that while an 'utopia' is an idea, or "'space" of the future', a 'heterotopia' is a 'space' that exists - literally 'other places' (Van Wyk 2014:4; also see Foucault \& Miskowiec 1986). Thus, a heterotopia is an 'other place' where the ideals of utopia are real. The importance of these descriptions is in drawing comparisons between what is happening, as in liturgical spaces of inclusivity and heterotopias. Within these heterotopias, the ideals of the Rainbow Nation and ubuntu are being realised; they are both visible and tangible. These heterotopias are 'other spaces' wherein the other is accepted and there is no fear of difference, as is noticed by the interviewees being willing to participate in group prayer and their openness to experience and partake in worship that was led by difference in the form of a traditional African choir. While Buqa (2015) is - not incorrectly - criticising what has been going on as not aligning with the ideals of the Rainbow Nation, there is empirical data showing other (liturgical) spaces and times where these same ideals 'are happening' in the midst of pluralistic, postcolonial diversity.

It is imperative to remember that while there is - and should be-inclusive prayer, where the examples above are impartial or open to such experiences, there is also exclusive prayer. This is when an individual can pray '... in honest, vulnerable expression of our own heart's longing' (Van Deusen Hunsinger 2009:366). An example of this has already been given above, where one of the interviewees said: '... I do pray alone but I also pray in a group'. This could occur in the event 9.Conducted between 28 February and 20 November 2016. 
that one believer's (or member of the vine or body) heart's longing(s) are different to those of other believers, thereby making said believer exclusive - even within inclusive prayer (Scott 2018:175). There is also the possibility for more 'exclusive' prayer within the 'church' to cultivate inclusivity, for example one of the interviewees feels called to pray with other people:

I feel it's part of my, let's say, 'calling' [...] to pray for other people ... um I am one of those, you know, when whoever it is preaches say that: 'there is a prayer team here, if anybody here feels they want to come to the rail' - I'm one of those that goes up. (p. 245)

Therefore, it can be suggested that what is going on exhibits inclusivity while also allowing for elements of exclusivity. It is important to mention that there is a distinct difference between exclusion and exclusivity, one is akin to segregation while the other is a choice made by the exclusive party or individual. At the beginning of this section, as an example of chosen exclusivity, it was mentioned that some of the interviewees chose to not take part in group prayer because they are shy or not extroverted. This is not detrimental nor contradictory to the ideals of ubuntu or the Rainbow Nation. None of the interviewees mentioned, complained or were concerned about being excluded - in most cases they complimented their congregations for the communities that they are. Within koinonia (or $u b u n t u$ ) there is a necessity for both inclusivity and exclusivity, the importance of which will be described in the next section (cf. Scott 2018:173-175). Another of the interview questions, that gave the interviewees the opportunity to list and describe what they would change about the worship service, ${ }^{10}$ is helpful in understanding what is going on. The context arising from the data related to the interview question is described in the subsection below.

\section{Minor adjustments}

One of the interview questions gave the opportunity for the interviewee(s) to contribute more directly by giving their informed opinion as active participants in the worship service (Scott 2018:51). In general, there were only minor alterations that were suggested. One of the interviewees, for example suggested the church's website needed to be updated and made more user friendly. Thus, as a mean across the three churches; nine participatory observations and nine semistructured interviews, it is understood that there was no want (culturally speaking) to challenge the status quo - or liturgical tradition(s). Adding to this, the majority of alterations that were suggested were more for the sake of the individual and thus more for the exclusive ' $I$ ' than the inclusive 'we' as can be seen by the example of the church's website. ${ }^{11}$ Other examples include one of the interviewees suggesting that meeting others for prayer should not be limited to the end of the worship service, while another two suggested there

10.The interview question asked: "In your opinion, should the worship service be adjusted so that worshippers could have better experiences of prayer?' (Scott 2018:51).

11.Such an alteration has little effect on either inclusivity or exclusivity; however, it is a change that would be made for the few rather than the many. It can be speculated that the website could affect inclusivity by allowing people with limitations to be part of the worship service via a live stream as a result of improving user friendliness. should be less rigidity with regard what is being prayed for. One of the interviewees made the following statement:

... I mean at one time, there's three-hundred people in $[\ldots]$ the church. And it's very difficult to keep everybody happy all at the same time, you know, you've got a group of people that like it done this way; you've got another group of people that prefer more music to preaching ... (p. 267)

The importance of sharing this is that it shows, from the perspective of those in the pews, that there is both inclusivity and exclusivity. Thus, ubuntu is being carried out. Furthermore, this suggests a situation similar to the idea of the Rainbow Nation. The quotation above aids in illustrating that while the rainbow is one inclusive whole, it is also the sum of several exclusive colours that are distinct, but also blend into one another. As a metaphor, the rainbow is a meaningful example of illustrating the tension between inclusivity and exclusivity by illuminating the ' $\mathrm{I}$ ' (one colour) within the 'we' (rainbow).

Therefore, it can be concluded that these churches are already conducting the ongoing process of liturgical inculturation, or that the worship is transcultural. In other words, the worship transcends culture at these churches which exist in a multicultural urban setting. Thus, creating heterotopias wherein Ubuntu is experienced - it is real. At this point, what needs to be remembered again in terms of Ubuntu being understood as 'I am because we are', is that within the inclusive 'we' is an exclusive identity, namely the ' $\mathrm{I}$ '. While the 'we' is important, the importance of the 'I' should not be overlooked.

\section{Rite or rhyme}

In the introduction, reference was made to Wolterstoff's (2011:19-21) description of a 'septuple rhythm', as well as the term way of life. This is in understanding 'that which is done on Monday through to Saturday is a reflection and/or continuation of that which is experienced on Sunday in the worship service' (Scott 2018:162). However, in congruence with the aphorism lexorandi, lexcredendi, lex(con)vivendi, this rhythm can also be regarded as a weeklong ritual. Some definitions or descriptions of ritual aid this notion:

Rites are not givens, they are hand-me-downs, quilts we continue to patch. Whether we call this activity ritual creativity, ritual invention, ritual making, or ritual revision does not matter as much as recognising that rites change, that they are also flowing processes, not just rigid structures or momentary events. (cf. Grimes 2000:12)

Coming together and pushing apart - intimacy and aggression, symbiosis and isolation - are some of the most basic rhythms from which ritualisation is constructed; hence, these actions are quite susceptible to habituation. Rites should not fail to deal with the systole and diastole of human action, but often they do. The result is habituation, the freezing of action. An unfortunate tendency of Western theories of ritual is to define ritual as if it were habituated behaviour. But habituation is the bane of ritualisation. It is imposed in the form of ought-filled, unmindful heteronomy, which is then hidden from view, denied. So authentic ... ritualisation should not be dismissed by linking it to the stifling rigidities of habituated behaviour (cf. Grimes 2010:35). 
Rituals are often repeated, self-evident, symbolic actions, that are always interactive and corporeal, sometimes accompanied by texts and formulas, aimed at the transfer of values in the individual or the group, and of which the form and content are always culture, context and time bound, so that the involvement in the reality which is presented in the rituals remains dynamic. (cf. Wepener 2009:36)

The entire seven-day week can be seen as one overarching Christian ritual with liturgical, communal, private, repeated, dynamic, interactive and valuable flowing performances that are not habituated. Due to said ritual being dynamic, it should not be prescribed that there is necessarily a daily performance. Therefore, this ritual can be popular devotion and private prayer every morning, attending a cell group on a Wednesday, and worshipping on a Sunday. It can also be attending Alpha course on a Thursday evening, and a youth group the following night. The importance lies in the performances being a result of faith, therefore it is not a case of liturgy versus labour, work versus worship, nor week versus sabbath. As an example of this, the majority of interviewees discussed how they pray daily - whether it was privately in the morning or evening, at a cell group, or during the worship service on a Sunday. Each of these instances of prayer shows an interpenetration of the sabbath and week rather than a separation between them.

\section{Liminality in the farewell discourse}

In the introduction, the allegory of the vine and the branches was mentioned in order to metaphorically illustrate the connectedness between Christians, but also - importantly with Jesus. ${ }^{12}$ This image portrays the two profound needs pointed out by Long (2001:30): ' ... we human beings hunger for both God and community, or to put it more precisely, we hunger for God in community', thus to be as a branch with other branches that are part of the vine. Firstly, this example can be used to describe the necessary tension between - and co-existence of -inclusivity and exclusivity. As each branch is its own exclusive piece (the ' $\mathrm{I}$ ') connected to the Vine (Jesus), as described by Malina and Rohrbaugh (1998:234): 'The metaphor of the vine and the branches describes a one-to-one relationship between disciple and Jesus.' The next sentence adds: 'That is the primary relationship and the basis for the relationships between disciples that flow from it.' While the Vine is Jesus in whom the branches are engrafted it is also the collection of all the branches (the 'we'). Thus, the entire vine is a collection of individual branches, which alludes to the proverbial branch (attached to the vine) exclaiming 'I am because we are', in terms of the concept of ubuntu.

However, within the farewell discourse there are examples of liminality, and the whole discourse is set in a transitional

12.John 15:1-6 (NIV) states: ' 1 am the true vine, and my Father is the gardener. He cuts off every branch in me that bears no fruit, while every branch that does bear fruit, he prunes so that it will be even more fruitful. You are already clean because of the word I have spoken to you. Remain in me, as I also remain in you. No branch can bear fruit by itself; it must remain in the vine. Neither can you bear fruit unless you remain in me. I am the vine; you are the branches. If you remain in me and I in you, you will bear much fruit; apart from me you can do nothing. If you do not remain in me, you are like a branch that is thrown away and withers; such branches are picked up, thrown into the fire and burned.' period, namely Jesus' departure (Wepener 2014b). The depictions, exhibit the process of transformation illuminating the important phase of 'betwixt and between', similarly to the current South African context. At a surface level, the liminality that can be seen, begins with the acknowledgement of an impending change - the realisation that a drastic transformation is in progress, after which a communitas is created: a space in which different forms of interrelatedness are created. An example of this is the relationship between Jesus and the disciples; the dynamic alters from a 'servantmaster' relationship to one of 'friends' (see Jn 15:13-17 ([NIV]). There are several different layers that reveal the ritual process(es) that include the so-called liminal phase. What is important here, is not which process to use as discourse, rather it is the example of a liminal phase. An important attribute of liminality is communitas (cf. Barnard 2010:70-71; Wepener 2014b:27-30). Thus, when examining the farewell discourse, a liminal phase is observed where Jesus and the disciples enter into communitas - a transitional space where human interrelatedness takes alternative forms; where an anti-society and therefore anti-structure is formed. This anti-structure is formed while Jesus explains the world hating the disciples; thus they - as friends with him - become the 'marginalised' as they are now part of the vine (cf. Malina \& Rohrbaugh 1998:237).

As mentioned above, there are several potential layers to describing the liminal phase that is depicted in the farewell discourse. One such layer to which comparisons can be drawn, is the ritual process of Jesus washing the disciples' feet. Before the ritual is enacted, the relationship between Jesus and the disciples is compared to that between servants and their master, this is known as the preliminal phase. Thus, the liminal phase will be the action of having one's feet washed through which one is forgiven. Thereafter, the relationship has been transitioned from its former state to the postliminal phase of friends. The importance of mentioning this, is to show that within the liminality of the farewell discourse, there are heterotopic examples of post-liminality. In other words, within the period of transformation depicted in John 13-17, there is also future spaces that are real or 'a time is coming - and has come' (citing Jn 16:32). On another layer, through the washing of feet and the last supper a communitas comes into existence. The preliminal phase then, could be Jesus' ministry and the postliminal phase of the disciples no longer belonging to the world, rather the vine in which they should abide and bear fruit by continuing what they had learnt in solidarity.

\section{Conclusion}

'What ought to be going on?', is the question associated with Osmer's (2008:129-173) suggested normative task. However, by asking such a question, it is apparent in the above that there is evidence that what ought to be going on, is already happening - albeit in the form of heterotopias. This is why this research question was originally asked: 'How could current liturgical praxis as heterotopia aid the development and imagining of ubuntu in South Africa?' 
This was answered by discussing and describing that, within these heterotopias, ubuntu - as an inclusivity and the acceptance of 'otherness' - does in fact exist. Based on the theory developed above in this article, liturgical aids can be developed (e.g., cf. Schoeman et al. 2015). Meanwhile there are these heterotopias where $u b u n t u$ is tangible, where it is real, where it does exist, where the ideals of ubuntu are present. South Africa is still in a liminal space between the fall of the apartheid era (preliminal) and utopia in the form of ubuntu, or the Rainbow Nation (postliminal). While South Africa is still heading toward a postliminal phase, the current heterotopias should - in future - address and embrace harder issues such as anger, colonialism, decolonisation, black pain, white privilege and more.

\section{Acknowledgements \\ Competing interests}

The authors have declared that no competing interest exist.

\section{Authors' contributions}

All authors contributed equally to this work.

\section{Ethical considerations}

This article followed all ethical standards for carrying out research without direct contact with human or animal subjects.

\section{Funding information}

This research received no specific grant from any funding agency in the public, commercial, or not-for-profit sectors.

\section{Data availability statement}

Data sharing is not applicable to this article as no new data were created or analysed in this study.

\section{Disclaimer}

The views and opinions expressed in this article are those of the authors and do not necessarily reflect the official policy or position of any affiliated agency of the authors.

\section{References}

Ackermann, D.M., 1998, 'Becoming fully human: An ethic of relationship in difference and otherness', Journal of Theology of Southern Africa 102, 13-27.

Babbie, E. \& Mouton, J., 2001, The practice of social research, Oxford University Press Southern Africa, Cape Town.

Barnard, M., 2010, 'Flows of worship in the network society: Liminality as heuristic concept in practical theology beyond action theory', In die Skriflig 44(1), 67-84, viewed 07 November 2016, from http://www.scielo.org.za/scielo.phpscript=sci arttext\&pid=\$2305-08532010000100005\&lng=en\&tlng=

Barnard, M., Cilliers, J. \& Wepener, C., 2014, Worship in the network culture: Liturgical ritual studies: Fields and methods, concepts and metaphors, Peeters, Leuven. (Liturgia condenda, 28).

Buqa, W., 2015, 'Storying Ubuntu as a rainbow nation', Verbum et Ecclesia 36(2), Art. \#1434, 1-8. https://doi.org/10.4102/ve.v36i2.1434
Chupungco, A.J., 1992, Liturgical inculturation: Sacramentals, religiosity, and catechesis, The Liturgical Press, Collegeville, PA.

DiAngelo, R., 2018, White fragility: Why it's so hard for white people to talk about racism, Beacon Press, Boston, MA.

Foucault, M. \& Miskowiec, J., 1986, 'Of other spaces', Diacritics 16(1), 22-27. https:// doi.org $/ 10.2307 / 464648$

Geertz, C., 1973, The interpretation of cultures, Basic Books, New York.

Grimes, R.L., 2000, Deeply into the bone: Re-inventing rites of passage, University of California Press, Berkeley.

Grimes, R.L., 2010, Beginnings in ritual studies, 3rd edn., Ritual Studies International, Waterloo, Canada.

Gubrium, J.F., Holstein, J.A. \& Marvasti, A.B., 2012, The SAGE handbook of interview research: The complexity of the craft, Sage, Thousand Oaks, CA. https://doi. org/10.4135/9781452218403

Long, T.G., 2001, Beyond the worship wars: Building vital and faithful worship, The Alban Institute, Albany.

Lunsford, A.A., Wilson, K.H. \& Eberly, R.A., 2009, 'The rhetoric of interdisciplinarity: Boundary work in the construction of new knowledge', in The SAGE handbook of rhetorical studies, pp. 265-284, Sage, Thousand Oaks, CA. https://doi.org/10. 4135/9781412982795

Lutheran World Federation, 1996, Nairobi statement on worship and culture: Contemporary challenges and opportunities, Lutheran World Federation, Geneva.

Lutheran World Federation, 1998, 'Chicago statement on worship and culture: Baptism and rites of life passage', Studia Liturgica 28(2), 244-252. https://doi. org/10.1177/003932079802800209

Malina, B.J. \& Rohrbaugh, R.L., 1998, Social-science commentary on the gospel of John, Fortress Press, Minneapolis, MN.

Osmer, R.R., 2008, Practical theology: An introduction, Eerdmans, Grand Rapids, MI.

Ponterotto, J.G., 2003, 'Brief note on the origins, evolution, and meaning of the qualitative research concept "thick description"', The Qualitative Report 11(3), 538-549, viewed 21 October 2016, from http://nsuworks.nova.edu/tqr/vol11/ iss $3 / 6$

Post, P., 2001, Christian feast and festival: The dynamics of western liturgy and culture, Peeters, Leuven. (Liturgiacondenda, 12).

Schoeman, F. (ed.), Kritzinger, A., Nthakhe, T.J. \& Wepener, C., 2015, Prayer guide for the season of human dignity, Biblecor, Wellington.

Scott, H.R., 2013, 'Transformation in the worship service: A ritual-liturgical exploration', MA mini dissertation, Faculty of Theology, University of Pretoria.

Scott, H.R., 2018, 'Praying, believing and being church: A ritual-liturgical exploration', PhD thesis, Faculty of Theology, University of Pretoria.

Smit, D.J., 2004, 'Lex orandi, lexcredendi, lex (con)vivendi? - Oriënterende inleiding tot liturgie en etiek', Nederduitse Gereformeerde Teologiese Tydskrif (NGTT) 45(3-4), 887-907.

Thiselton, A.C., 2015, Systematic theology, Eerdmans, Grand Rapids, MI.

Thumma, S.L., 1998, 'Methods for congregational study', in N.T. Ammerman, J.W. Carroll, C.S. Dudley \& W. McKinney (eds.), Studying congregations: A new handbook, pp. 196-240, Abingdon Press, Nashville, TN.

Turner, V.R., 1995, The ritual process: Structure and anti-structure De Gruyter, New York.

Van Deusen Hunsinger, D., 2009, 'Practicing Koinōnia', Theology Today 66(3), 346-367. https://doi.org/10.1177/004057360906600306

Van Gennep, A., 1960, The rites of passage, Routledge \& Kegan Paul, London.

Van Wyk, T., 2014, 'Church as heterotopia: Original research', HTS: Theological Studies 70(1), 1-7. https://doi.org/10.4102/hts.v70i1.2684

Volf, M., 1996, Exclusion and embrace: A theological exploration of identity, otherness, and reconciliation, Abingdon Press, Nashville, TN.

Wepener, C.J., 2006a, 'Participation and power: Opportunities for method and theory in liturgical research from a changing (Dutch Reformed) South African liturgical landscape', Jaarboek voor liturgie-onderzoek 22, 49-66.

Wepener, C.J., 2006b, 'Ritual route markers for reconciliation: Insights from a South African exploration', Studia Liturgica 36(2), 173-184. https://doi.org/10.1177/ 003932070603600204

Wepener, C., 2009, From fast to feast: A ritual-liturgical exploration of reeconciliation in South African cultural contexts, Peeters, Dudley.

Wepener, C., 2014a, 'Liturgical inculturation or liberation? A qualitative exploration of major themes in liturgical reform in South Africa', HTS Theological Studies 70(1), Art. \#2644, 1-8. https://doi.org/10.4102/hts.v70i1.2644

Wepener, C., 2014b, Van voor die wieg tot na die graf, Bybelkor, Wellington.

Wepener, C.J., 2015, Boiling point! A faith reaction of a disillusioned nation - Reflections on anger, Biblecor, Wellington.

Wepener, C. \& Barnard, M., 2010, 'Entering the field: Initiating liturgical research in an AIC', Acta Theologica 30(2), 192-210. https://doi.org/10.4314/actat.v30i2.67268 Wolterstoff, N., 2011, Justice in love, Eerdmans, Grand Rapids, MI. 